Hare, F. K., R. W. Kates, and A. Warren, 1977. "The Making of Deserts: Climate, Ecology, and Society", Economic Geography, Vol. 53, No. 4, pp. 332-346.

\title{
THE MAKING OF DESERTS: CLIMATE, ECOLOGY, AND SOCIETY
}

\author{
F. KENNETH HARE \\ University of Toronto \\ ROBERT W. KATES \\ Clark University \\ ANDREW WARREN \\ University College, London
}

In origin deserts are natural phenomena. Desertification, the aggravation or extension of such conditions, is a human phenomenon that arises from society's search for secure livelihoods in dry environments. Even where this search is successful some environmental deterioration is inevitable. In those instances where the pursuit of life and security goes awry, destructive processes are set in motion, the productive base deteriorates, and the social system is imperiled. These desertification processes, unlike the one- to five-year periods characteristic of drought, are long-term, chronic, and pervasive; yet, these same long-term processes are intimately affected by short-term climatic variability and by changes in human social systems at varying scales.

Often this interactive process acquires a synergistic quality, where the very remedies for desertification become part of the hazard's causal mechanism. While this multi-faceted, intricately interwoven aspect of desertification complicates attempts to unravel cause from effect in the desertification process, three fundamental questions are discernable. First, to what degree is the inherent variability of climate, possibly coupled with climatic change and human activity, responsible for desertification? Second, can the ecological evidence for desertification be untangled from a morass of ob- servational problems, temporal uncertainties as to trend, and ambiguities as to the areal extent of afflicted regions? Finally, what are the human dimensions, the causal mechanisms and the human impacts, of desertification? Answers to these fundamental questions, together with remedial suggestions, are the focus of this paper.

\section{The Role of Clmmatic Variability}

Climates of the desert margin are characteristically variable, especially as regards rainfall. Undisturbed ecosystems take full account of this variability, for they are able both to survive prolonged drought and to take full advantage of the short periods of abundant water supply. Almost every species is adapted in some way in both these senses. The physiognomy of the vegetation, moreover, provides (in ways that are often subtle) a shelter to the soil. Ancient human societies of the desert margin were similarly adapted, although often at a cost the modern outlook finds it hard to bear.

The record shows clearly that the desert margin shifted appreciably during the Holocene (the past 10,000 years), and that some of these shifts must have been due to natural variations in rainfall. Nomadic herdsmen made extensive use of savannas in regions that are now 
some of the most sterile parts of the Sahara. The end of this period of relatively high rainfall appears to have come about 4,700 B.P. [17]. A similar desiccation occurring about a millennium later hastened the extinction of the Indus cultures [47]. Though it has been argued that even in these cases unwise land use may have contributed to the desiccation, the bulk of the evidence favors a natural origin for the harshening.

Recent desertification cannot be ascribed to variation of the long-term macroclimate (the large-scale behavior of the atmosphere and its associated weather patterns). As far as we know there have been no prolonged variations of consistent sign in any part of the arid zone. Progressive declines of rainfall lasting one or two decades are commonplace (Figure 1), being followed as a rule by abrupt returns to higher values. Such fluctuations are part of the ordinary behavior of arid climates. Recent advances of the desert edge, or spotty deteriorations of semi-arid and sub-humid ecosystems, have generally involved the interaction of such natural, temporary phases of desiccation with human and animal population dynamics or the extension of rain-fed cultivation.

Such periods of desertification are themselves episodes of increasingly hostile microclimates. This means that the climate near the ground, dominated by the exchange processes of water, carbon dioxide, momentum, heat, and nutrients that are crucial parts of ecosystem function, provides fewer resources for living organisms. If grass and shrubs are overgrazed to the point of extinction, the soil becomes naked and subject to ready wind or sheet erosion. It also becomes hotter and more reflective to solar radiation. These changes are all hostile to the resumption of vigorous life when the rains return, and may act as positive feedbacks tending to enhance the aridity of the macroclimate and to reduce the availability of nutrients and organic material within the soil. In this sense de- sertification is hostile climatic variation. But the evidence is that these feedbacks do not permanently prevent the reestablishment of more humid conditions when the macroclimate swings in that direction.

Figures 1 and 2 are representations of recent rainfall fluctuations in Sahelian Africa and at equivalent rainfall stations in comparable climatic regions of Australia and North America. From these and other evidence we can generalize as follows:

(1) There are large interannual variations of rainfall throughout the arid zone. Most of these variations occur because of the presence or absence of a small number of heavy thunderstorms, whose distribution is highly capricious. Hence, pastoralists and dryland cultivators enter each rainy season with no assurance that significant rain will fall early in the season. It may be necessary to defer field operations dangerously late.

(2) There is a distinct tendency for dry or wet years to follow one another in succession [54], to an extent well beyond random expectation. In each farmer's lifetime there is likely to be at least one destructive drought lasting three, four, or even five years. But there will also be an equivalent period of good conditions in which it is easy for him to forget the hazards of the climate.

(3) In certain areas prolonged downward trends may occur for one or two decades so that there is a progressive desiccation of the landscape and increased stress on all resources.

The Sahelian drought of 1968-1973 displayed all these characteristics. As Figures 1 and 2 show it was actually the culmination of a regional phase of desic- 

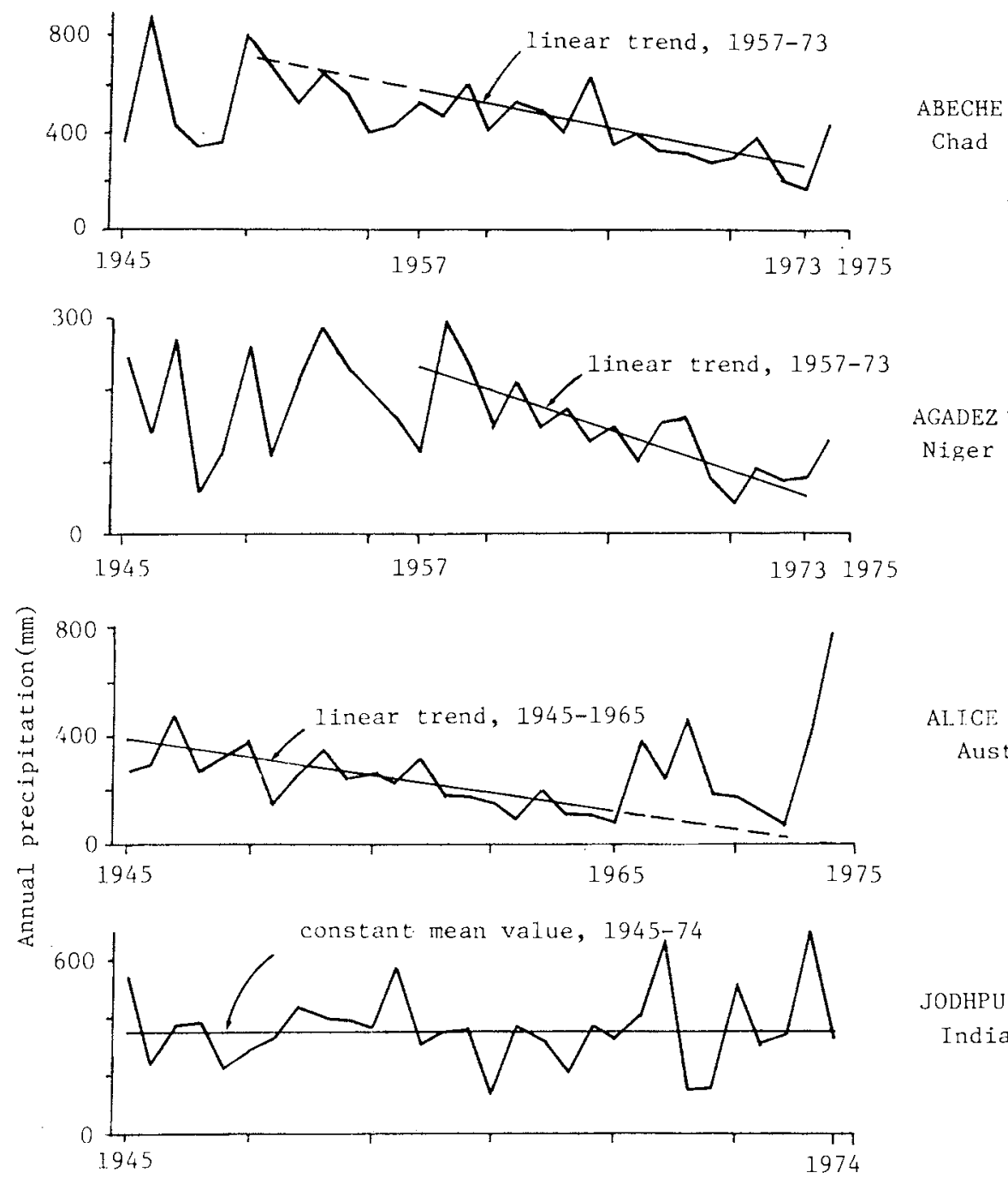

AL.T.CE SPRINGS

Australia

JODHPUR

India

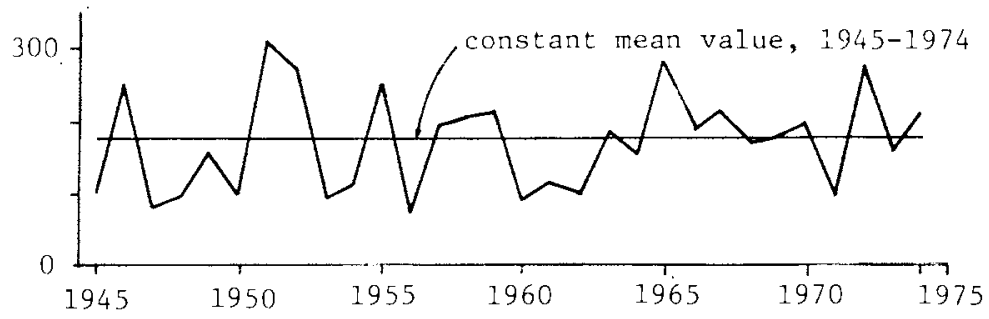

PHOENIX

U.S.A.

Fig. 1. Rainfall variations since 1945 at selected arid-zone stations. Note persistent linear downward trends lasting many years at Abéché, Agadéz, and Alice Springs terminating in heavy rains, and lack of visible trend at Jodhpur and Phoenix. 

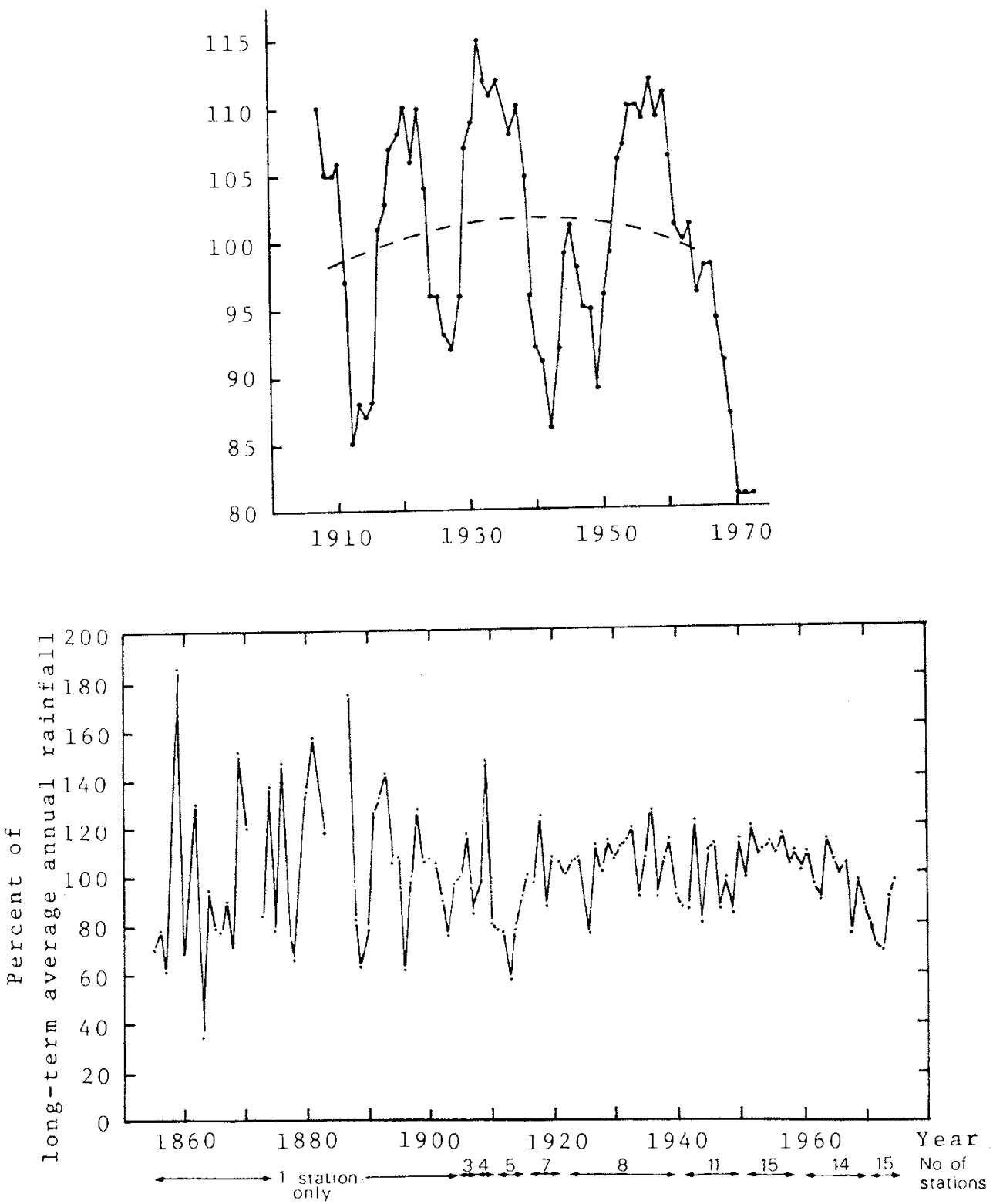

Fig. 2. Overall spatial average precipitation in Sahelian west Africa. Upper curve shows fiveyear values, 1905-1970, expressed as percentages of the average for the period, with long-term trend added. The lower curve gives annual averages for all available stations since 1857. The Sahelian drought of the early 1970s, though severe, is not unprecedented. Source: Mason [31].

cation that began in 1955-1960, but went interannual variability [51]. In parts of unrecognized by most external observers. At many individual stations this appears in the record as a linear decreasing trend, accompanied by a diminished east Africa the early 1960 s were a period of dramatically increased rainfall and stream flow, which after several years gave way to renewed desiccation. 
There is also a strong suggestion (Figure 2, upper curve) of quasi-cyclic variations of rainfall of periods of one, two, or three decades. The longest of these apparent rhythms is also visible in the discharge of the Niger and Senegal rivers, which derive their waters from the rainforested hills nearer the Guinea coast, and then flow north into the Sahel [43]. Much the same is true of Lake Chad and its contributaries. In Australia the flow of exotic streams displays similar fluctuations. In no cases, however, have such periodicities been established with sufficient confidence to justify their use in prediction.

Much attention has been given in the past three years to the possibility of feedbacks and interdependencies affecting the desert margins of the earth. The subtropical climates as a whole have long been known to exhibit such effects, and it is possible that there is predictability in some of them.

Destruction of surface vegetation by overpasturing or by cultivation tends to increase the surface albedo (i.e., reflectivity to solar radiation), especially during the dry season. It is known [6] that the Saharan-Arabian-Iraqian desert belt is actually cooled radiatively in the summer months at the top of the atmosphere; incoming solar radiation, though intense, is strongly reflected back, and the desert surface and lower atmosphere are cooled by infrared radiation escaping upwards into space. This net cooling must intensify the lower atmospheric subsidence normal to subtropical latitudes, and hence reinforce the aridity of the climate. Dynamical modelling of this effect by several authorities suggests that an increase in albedo caused by poor land use should lead to still further reductions in rainfall, and, in the case of the Sahara, to a southward shift in latitude of the desert edge. These models are too crude for certainty, but lead to the interim conclusion that man's over-use of the drylands may affect the climate adversely.

Interdependencies are more easily re- vealed, and have some potential for prediction, on the seasonal scale. It has recently been established that rainfall in Ceará Province of northeast Brazil is significantly and positively correlated with sea-surface temperatures in the tropical Atlantic up to three months previously [29]. Rainfall in the Sahel and streamflow in other parts of north Africa have been correlated significantly with rainfall over the Caribbean area [21]. Rainfall in the dry northern areas of Australia is apparently controlled in part by the so-called "Southern Oscillation" [42], which is a striking longitudinal circulation mechanism in the tropical Pacific and southeast Asia. Research into such interdependencies, especially those involving sea-surface temperatures, is now intense, and further encouraging results are very probable. It is clear that attempts to model climatic variation in the tropics must take account of such teleconnections.

Contemporary desertification episodes are the effects of interaction between mounting pressure on land and vegetation and the incidence of naturallyoccurring droughts, which are a normal part of the desert margin climates. It is possible that desertification amplifies itself by means of the albedo feedback mechanism described above, but the large-scale climate is, in the end, able to reassert more humid conditions. Damage to ecosystems during desertification may, however, make the recovery of surface productivity lag well behind the climate.

\section{Ecological Change and Desertification}

Desertification, defined as a persistent decline in the production of dry ecosystems, may be a pragmatic concept, but it is hard to pin down. For, if there is little evidence to suggest a secular change in climate as the causal mechanism in desertification, there are equal difficulties in assessing the role of drought in promoting degradation. Dryland spe- 
cies have adapted to survive seasonal, decennial, or longer-term droughts [37; 38]; plant and animal populations are regularly decimated, but their very existence testifies to their resilience. "Natural" fluctuations in production cannot, therefore, be called desertification, so much as endemic hazards; but it is not always easy to distinguish between the two on the ground.

There is much wider agreement with the proposition that recent droughts have merely accentuated a process of "cultural desertification." Too intense or unwise land use, in which there has been little or no investment in defenses against environmental hazards or degradation, is commonly said to have sapped the resilience of dry ecosystems. Drought has simply administered the coup de grâce, leaving ecosystems with more persistently or even permanently reduced productivity than they suffer from drought alone.

There is no doubt about the desertifying role of irrigated agriculture, especially in the Middle East [13]. In Pakistan between 20 and 45,000 hectares per year were said to be salinized each year in the early 1960s, and in Iraq the effect of severe degradation in the early historic period is still in evidence [12]. Total production from irrigated agriculture has only been able to keep a few steps ahead of desertification by introducing better methods and increasing the irrigated acreage.

Rain-fed agriculture is frequently blamed for widespread desertification, but the extent of the damage and its etiology are debatable. Parts of North Africa, which today appear only fit for poor grazing, were undoubtedly important producers of cereals for the Romans, but there are many different interpretations of this evidence. While Mensching and Ibrahim [33] attributed widespread wind and water erosion in southern Tunisia to early agriculture, Vita-Finzi [53] questioned whether erosion was due to agriculture or to a climatic change.
He pointed out that while erosion has always occurred, it has not always been seen as a disadvantage. In northern Libya many small dams were built specifically to trap the eroded sediment and to create deep, well-watered soils for agriculture. Roman agriculture could have expanded in a short period of favorable rainfall, much as agriculture expanded into the northern Sahel in the early 1960s. The Romans, like the Hausa, may have had to retreat in the face of a drought and what was, in effect, only a marginal increase in erosion.

The case against Old World pastoralists is even more murky than that against farmers. Nomadism is the most resilient of land use strategies using a whole range of subtle and generally effective methods for dealing with its harsh and erratic environment. But has the environment been damaged by these methods? The evidence is not clear. At Avdat in Israel a plot of the common Artemesietum plant community did not change its composition even when sheep had been excluded for several years [14]. Does this mean that all the possible plant invaders have been removed by selective grazing from the whole of the surrounding area, leaving no seed sources, or that recovery is very slow, or that it must await a very rare good season. Or has grazing not damaged the resource at all? The more common experience with exclosures is that they show remarkable recovery in a short period of time. But does this mean that damage is in fact not serious, and resilience is maintained, or (the more common interpretation) that production could be greater? It is well known that pastures under moderate grazing are much more productive than those left to themselves: pruning by nibbling encourages growth and grazing animals are better cyclers of nitrogen than soil fauna [34].

But the case against pastoralism is still more complex. In a zone with a long and eventful history, do we attribute degra- 
dation, if indeed it has occurred, to nomadic strategies themselves or to the external pressures to which these people have been constantly subjected? Or must we reopen the environmental determinist argument of Elsworth Huntington and Ellen Semple, invert the argument, and attribute the fluxes of history to environmental change, perhaps itself culturally induced? These are emotive issues, since they impinge on modern decisions about how to plan the future of different ways of life.

In the New World and Australia, where history is shorter but better documented, there is no less confusion in interpreting the facts. Yet even agricultural statistics are difficult to interpret, as the examples of sheep numbers in the western division of New South Wales illustrates (Figure 3). This graph could indicate that the huge sheep populations of the 1890s so overgrazed the range that it was unable to recover, and never supported such numbers of sheep again. But there are many other possible explanations. There may have been a change in production per beast, or the throughput rate of beasts, or age at selling, or the demand for and price of meat or wool, or the returns from wool farming, or the attractiveness of sheep-farming as a career, or the structure of taxation and subsidies.

These "news lands" also bring home one last lesson about desertification: it is as much a cultural as an ecological problem. The Kababish of central Sudan could support perhaps 100 people on the same land as is occupied by 10 West Australians. These two groups have different thresholds of tolerance, standards of living, expectations, perceptions of the environment, and technologies. In Australia and North America there has been a fundamental change in approach within the last century. Old techniques and attitudes might have maintained desertification. New ones have increased production.

Although desertification is difficult to detect at the regional scale, there can be no doubt that it exists on the ground. Numerous trained observers have made irrefutable claims that many parts of the dry world have suffered severely from ill-conceived land use policies $[3 ; 26$; 35]. Environmental and cultural qualincations of the concept concern the point along a continuous scale from "pristine" to abiotic at which desertification is deemed to have occurred.

In irrigated agriculture the scale is one of increasing salinity and waterlogging. To those who want to grow peaches, desertification begins at the slightest touch of soil salting; for dates, which can stand much saltier conditions, desertification would be postponed. Salinization occurs if the inevitable concentration of salt in irrigation water that follows evaporation and plant uptake is not flushed out of the soil with more water. Salt concentration inhibits water uptake by the crop, and yields are first reduced and then eliminated. Salinization and waterlogging are known in practically every irrigation project. Many suffer an additional, serious long-term problem with downstream concentration of salt. This is experienced in large schemes such as those along the Colorado, Rio Grande, Indus, or Murray Rivers $\{22\rceil$. Here upstream users pass on problems to those lower down the valley.

In rain-fed agriculture and pastoralism early damage is subtle. Fields slowly lose soil organic matter and nitrogen, and soils gradually become less well aggregated. In pastures, the desirable, nutritious plants may be grazed too hard for their survival, and trampling breaks up soil aggregation and reduces permeability. These processes can usually be countered with traditional techniques such as fallowing or with newer methods such as fertilizer application or reseeding. Their significance to desertification is that, though often reversible, they reduce the resilience of the ecosystem and render it more vulnerable to extreme climatic events. 


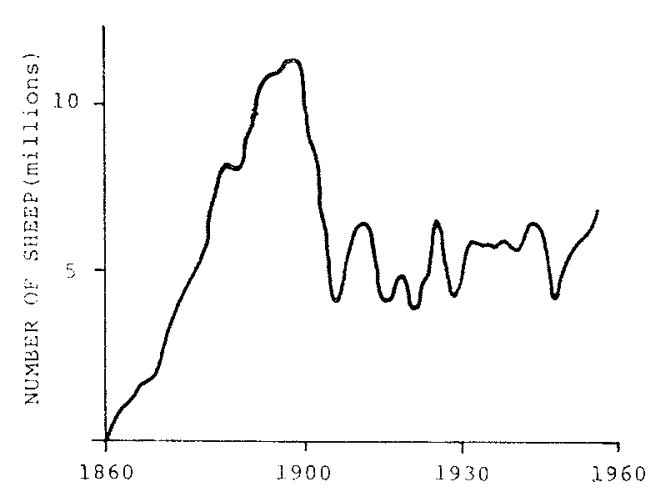

Fig. 3. Sheep numbers in the Western Division, New South Wales, 1860 to 1955.

It is these events-the few strong winds of the dry season, the once in a year heavy rainstorm, the decadal drought-that push an already damaged agricultural or pastoral ecosystem over to a state of more permanent degradation. Bared, poorly aggregated fields or denuded, hoof-pounded pastures are likely to be whipped by the wind into dunes or to be denuded by it to leave a barren, hardened "scald" on the infertile subsoil [30]. Rainstorms which only occur once or twice a year in west Africa may remove topsoil and create a network of deep, inconvenient gullies across the fields [15].

Accelerated erosion is not a problem that is peculiar to dry areas, but it is much more damaging there. Arid soils are much shallower than humid ones, and contain a far higher proportion of their nutrient store in a thin topsoil [5] with a permeable structure, which allows easy percolation. Soil erosion removes both the nutrients and the permeability to leave a poorer surface, on which recovery of the vegetation will be very slow. It is at that point that few observers would doubt that desertification had occurred. A gullied field or one stripped of soil to the hard bedrock may be forever uncultivable. Land stripped of topsoil may recover lost forage productivity only over centuries. Sandy land that has been molded into active sand dunes may take a decade to restabilize. Agricultural and pastoral land use are the greatest agents of desertification, but not the only ones. Firewood-gathering, traffic corridors, and mining are also destructive uses. The first makes an impact over extensive areas [8], while the last two are more localized but can be intensely damaging.

The evidence for desertification at a local scale seems incontrovertible. It is most obvious at this scale because it is here that the interactions between the human system and its resource base are most intimate and intense. Linkages at regional and global scales also exist, but their connection to desertification processes is less direct and less easily established. It is to these larger-scale issues that we turn in attempting to assess the social causes and consequences of desertification.

\section{Social Causes and Congequences of Desertification}

Six hundred and thirty million people live in drylands, and between 50 and 78 million of this population inhabits districts exposed to severe desertification [25]. While the evidence for the extent of desertification is ambiguous, it is nonetheless very real for those affected. However, vulnerability to the hazard varies considerably. Economic status or urban residence shield many, while some livelihoods, such as the animal-based ( 6 percent of the dryland population but 22 percent of the risk-prone), are disproportionately exposed to risk.

In addition to fluctuations in climate and the deleterious impacts of livelihood activities on the environment, two major patterns of change in human society have causal importance in desertification. The first of these is population dynamics, for both growth and decline in population cause desertification. The second pattern involves changes based on the interaction of society at varying scales. Three 
types of social change seem to have paramount importance: (1) integration into wider socioeconomic systems which alters the dynamics of local livelihood systems; (2) the invasion of new and the retreat of old technologies that truncates the evolution of indigenous expertise; and (3) the fluctuating strength and effectiveness of governments which drastically affect stability and survival in the dry margins. Out of these interactive processes develop the events that lead to desertification and its salient consequences: loss of resource base productivity, deterioration in health and wellbeing, and migration. And finally, societies respond to desertification with a variety of coping mechanisms whereby its effects are absorbed or accepted, its consequences are reduced, or its pressures are translated into change in livelihood or location.

Demographic change, an alteration in the number of people depending on the resources of the drylands, is the most dramatic process of social change associated with desertification. Often imbalances caused by population growth or concentration place increased pressure on the local resource base. When this occurs, the intensified utilization of the resource base without compensating increases in productivity can lead to the long-term deterioration characteristic of desertification.

But the apparent correlation between population growth and environmental deterioration can lead to facile conclusions [11]. Not all livelihood systems are growing at the same rate, and there is some evidence to suggest that pastoral groups are experiencing little or no increase $[4 ; 44]$. Deterioration in pastoral sectors would seem to be the result of other factors, such as the expansion of rain-fed agriculture or the increase of herd size in response to market opportunities, rather than a need to provide support for more people. Much of the population growth has been concentrated in the agriculture- and urban- based sectors in closer contact with modern medical science and sanitation. But even in these situations population increase does not necessarily result in desertification, for a study of population densities indicates that great variation exists, even among peoples who inhabit homologous climatic regions. Both northern Nigeria near Kano and Rajasthan in India [48] are able to maintain populations in excess of 150 per square kilometer, a figure well above that of most analogous zones. These densities reflect the national settings of the drylands and the great variation in the productivity of the different livelihood complexes employed. The existence of these population concentrations encourages optimism about the flexible and dynamic ability of drylands to support human populations. Moreover, rural depopulation can also be a contributor to desertification. Outmigration of economically active rural people may increase levels of living in the short term. But in the long run, competition for labor between rural and urban spheres tends to undermine the viability of rural livelihoods which require intensive labor or specialized knowledge. This appears to be occurring in Yemen, where a massive labor migration to Saudi Arabia is undermining the maintenance requirements of Yemeni terrace agriculture [9]. As a consequence, the productivity of the local resource base is likely to decline despite the buttressing effect, which may be only temporary, of remissions from migrants.

To the extent that population growth exacerbates desertification, a prolonged worsening of conditions can be anticipated in many rural and most urban areas of the developing world. For those livelihoods, such as pastoral nomadism which has not experienced pronounced growth, rapid increases in population growth can be anticipated as medical care becomes more widely available and sedentarization occurs [56]. In the dry rural areas of developing countries, the imbalances will be the product of a 
steady reduction in death rates with continued high birth rates. Urban populations will grow at even higher rates because of both immigration and local growth, for as health improvements are made in rural areas population gains will be unable to be absorbed without migration. Only countries with controlled settlement policies appear able to moderate these rural to urban flows of population by emphasizing the economic viability and social well-being of the countryside $[7 ; 50]$.

A more complex process is the impact that world integration and specialization has had on the traditional livelihood practices and adaptive techniques of dryland peoples. Formerly isolated and selfsufficient, they are now integrated into market structures over which they have no control and for which they are now expected to become specialized producers. While some make this transition successfully, sending primary products over great distances to urban markets, many find that old livelihood strategies no longer suffice and that survival becomes increasingly difficult as both the natural and cultural components of their ecosystem deteriorate. O'Keefe [39] demonstrates the development of this process at the village level in Kenya. The impact of drought becomes even more severe under these circumstances and recovery based on indigenous resources alone is difficult. Yet peripheral location and constrained development prospects restrict the flow of aid for recovery and growth. In extreme cases, the productive base may be so degraded that people are forced to abandon their traditional livelihood and habitat entirely.

The diffusion of new technologies into traditional societies, often carried out rapidly, at an unsuitable scale, and with incomplete integration into the local cultural setting, can accelerate and worsen desertification pressures. Much of the devastation of the Sahelian drought and its longer-term consequences flowed from incomplete integration of well technology into the local pastoral culture [41]. Talbot [49] has reported similar problems with rangeland management schemes in east Africa where technological improvements released constraints on herd sizes in the traditional pastoral economy and new management controls were not substituted. The expansion of irrigation has had the effect of driving out of production marginal drylands that are the main subsistence support of Mexican peasants [23], and nomadic herders in Rajasthan have encountered similar difficulties as grazing land is converted to crop production by the expansion of irrigation [28]. The introduction of new technologies truncates the balanced evolution of local systems of production and desertification control that contain time-tested principles of dryland management. Often the exotic techniques are inappropriate to the objectives, experience, and skills of the local populace and cannot be properly absorbed without destroying local traditional expertise. The loss of livelihoods and local wisdom with proven viability is a serious contributor to the desertification process.

Government actions also promote both positive and negative desertification consequences. Thus, the government that provides the security, technology, and organization to extend irrigation into new districts often spreads salinization as well. Moreover, the system created becomes dependent on the integrating and maintaining activities of the central administration. The evidence for the periodic collapse of dryland systems is proof of the vulnerability of the new creation $[1 ; 18 ; 24]$. And the demands of both governments and landlords for increased production can be the factor that encourages overexploitation and subsequent collapse [18] or the extension of settlement into areas fraught with desertification difficulties [32]. These examples suggest the often paradoxical and ironic nature of desertifica- 
tion, where greater production brings increased risk and vulnerability, and solutions become the forerunners of enhanced difficulties.

The interaction of these social processes with climatic variability and ecological change results in the consequences of desertification. The impact of these consequences is best noted in their impress upon small social groups, a perspective that is more fully developed elsewhere in this issue, but a few general consequences bear discussion. Loss of resource base productivity is the most serious consequence of desertification. Industrialized and urban livelihoods possess the resources to cope with or transcend the effects of productivity loss, but small groups and individuals are less fortunately placed. Peripheral location and status, and ineffectual claims upon limited available resources, means that diminished health, social stress, stagnation, and migration as well as the abandonment of time-honored ways of life constitute the human experience of desertification.

Change in the health and well-being of populations exposed to desertification is an important consequence, but it is not well understood. A decrease in resource base productivity would seem to have a straightforward connection to nutritional deficiency and ultimately starvation, but there is no clear evidence of adjustment to such conditions over a considerable period. Most existing information relates to drought $[16 ; 19 ; 45 ; 46]$ and the malnutrition associated with it. While drought is clearly an exacerbating factor in desertification, it is difficult to determine how much ill-health is drought induced and how much reflects longer-term conditions of gradual diminution and loss. Other diseases also fail to exhibit a close linkage to desertification, being more directly related to general changes in environment or location [40]. The psycho-social stress associated with desertification is not unlike that of any group caught in the toils of rapid and unwelcome social change $[2 ; 2 \%$; 52]. Indeed, given reasonable opportunity to adapt to change on their own terms, there is evidence to suggest [10] that traditional cultures can not only cope with altered conditions but also make positive contributions to retarding and reversing desertification.

Migration is impelled by desertification and is one of the major responses to it, but its consequences are surrounded by ambiguity. A return to desertified districts is often impossible, and frequently migrants themselves do not desire to return. This is due both to the diminished productive possibilities at home and to the substantial advantages in improved living standards, security, and status that often accrue to the migrant. Paradoxically, the very success of migrants in adapting to economic opportunity threatens the survival of indigenous livelihood systems [36]. The shift of labor to new activities undercuts the productive potential of traditional livelihood forms, diminishes contact with traditional social institutions, and marginalizes those who remain behind.

\section{Combatting Desertification}

Every effort should be made to understand and cope with desertification, to minimize the ecological impact of resource use in order to avoid contributing to the desertification processes, and to assist individuals and groups affected by desertification. These measures and principles take a number of forms, but all of them spring from a concern for human systems as the central focus of desertification's causes and consequences.

Among the meteorological measures that can be recommended to mitigate the effects of climate variability are the following:

(1) maximum use of existing climatological records to ensure that the element of surprise and strategic vulnerability is minimized; 
(2) search for seasonal and interannual predictability, by means of modelling exercises and interdependencies with time lags and other periodicities that may be revealed by research;

(3) attempts at weather modification where appropriate by cloudseeding and other techniques (but not large-scale greenbelt plantation, unless the latter is aimed mainly at soil stabilization and fuel production );

(4) use of satellite imagery to improve forecasting of rainstorms and their displacement; and,

(5) extension throughout the lands subject to the desertification hazard of the best available meteorological forecasting and advisory services, under international sponsorship.

The numerous disruptions in dryland ecosystems that are characterized as desertification can be controlled if sound land-management principles are employed. The most important of these ecological principles are:

(1.) Recognize some concept of sustained yield. In the short-term it may be possible to extract more than a steady-state yield, but such exploitation runs the danger of reducing resilience and, thus, the long-term yield. This principal underlies an injunction to discover "carrying capacities" for each different set of cultural and environmental circumstances and then to adhere to these.

(2) Develop land use strategies that treat the dryland ecosystem as a whole. In planning land use strategies it is wise to consider traditional land users as an integral part of the current ecosystem.
(3) Strike a balance between inputs and outputs from drylands. The low output of drylands does not allow great investment, and the land user must rely much more on the stabilizing controls from within the semi-natural ecosystem itself. These controls, which maintain resilience, therefore, have economic importance and must be safeguarded.

(4) Maintain a flexible and mobile spatial and temporal pattern of use.

(5) Fit land use to land resource. At a given technical, organizational, financial, or moral input some land is suitable for one purpose, some for another. An inappropriate land use will eventually bring desertification. Land capability should be determined and some form of zoning should be planned.

Vulnerability to desertification is highly selective and most of the $50 \mathrm{mil}-$ lion people exposed directly are numbered among the poorest or inhabit the poorer nations. Their difficulties stem more from social, economic, and political problems than technical and physical ones. While general prescriptions are difficult, selective, flexible, and sustained efforts that follow general priorities promise to be the most useful:

(1) Assist the most vulnerable. The limited available resources need to be directed to reducing the threat of desertification for the most vulnerable peoples on the basis of vulnerability analyses sensitive to the economic, social, and political contexts of people.

(2) Address the root causes by facilitating outmigration where local resource-use options are inadequate to support a growing population and by maintaining viable and diversified livelihood sys- 
tems. This should take precedence over the optimization of any single product system.

(3) Cope with the consequences. Investment made to stem loss of productivity will yield maximum social benefit if it complements existing coping strategies and reinforces the viability of rural life. The health care of desertification-affected populations can best be provided, and the bad effects of productivity loss best countered, by using trained indigenous individuals to provide primary care with support from modern communications technology and centralized medical facilities. Anti-desertification projects that involve local participation in training programs, resettlement schemes, and development efforts are the most promising way to facilitate movement and promote productive economic growth.

\section{Literature Cited}

1. Adams, Robert M. Land Behind Baghdad: A History of Settlement on the Diyala Plains. Chicago: University of Chicago Press, 1965.

2. Benyoussef, J. et al. "Health Effects of Rural-Urban Migration in Developing Countries: Senegal," Social Science and Medicine, 8 (1974), pp. 243-58.

3. Boudet, G. Les Pâturages sahéliens: les dangers de dégradation et les possibilités de regeneration; principes de gestion ameliorée des parcours sahéliens. Maisons Alfort, France: FAO/TEMUT, 1976.

4. Caldwell, John C. The Sahelian Drought and Its Demographic Implications. OLC Paper No. 8. Washington, D.C.: Overseas Liaison Committee, American Council on Education, 1975.

5. Charley, J. L. and S. L. Cowling. "Changes in Soil Nutrient Status Resulting from Overgrazing and Their Consequences in Plant Communities of Semi-arid Areas," Proceedings of the Ecological Society of Australia, 3 (1968), pp. 28-38.
6. Charney, J. "Dynamics of Daserts and Drought in the Sahel," Quarterly Journal of the Royal Meteorological Society, 101 (1975), pp. 193-202.

7. Chen, Cheng-Sian. "Population Growth and Urbanization in China 1953-1970," Geographical Review, 63 (1973), pp. 55-72.

8. Delwaulle, J. C. "Désertification de I'Afrique au sud du Sahara," Bois et Forêt Tropiques, 149 (1973), pp. 3-20.

9. Dow, Michael. "Trip Report: Visit to Sana'a, Yemen Arab Republic, December 2nd-8th, 1975." Washington, D.C.: National Academy of Sciences, 1975.

10. Draz, O. Report to the Government of the Syrian Arab Republic on Range Management and Fodder Development. Rome: FAO, 1974.

11. Eckholm, Erik P. Losing Ground. New York: W. W. Norton, 1976.

12. El Dujaili, M. and G. Ishmail. "Irrigation and Drainage," Baghdad Salinity Seminar. Rome: FAO, 1971. Cited by A. P. A. Vink. Land Use in Advancing Agriculture. New York: Springer Verlag, 1975.

13. El Gabaly, M. "Problems and Effects of Irrigation in the Near East Region," in Arid Lands Irrigation in Developing Countries. COWAR Symposium. Cairo: Academy of Scientific Research and Technology, 1976.

14. Evenari, M. "Personal Communication." 1976.

15. Fournier, F. "Research on Soil Erosion and Soil Conservation in Africa," Sols africains, 12 (1967), pp. 53-96.

16. Gebre-Medhin, Mehari. "Famine in Ethiopia," Ethiopian Medical Journal, 12 (1974), pp. 105-07.

17. Geyh, M. A. and D. Jäkel. "Spätpleistozäne und holozäne Klimageschicte der Sahara aufgrund zugänglicher $\mathrm{C}^{14}$-daten," Zeitschrift für Geomorphologie, 18 (1974), pp. 82-98.

18. Gibson, McGuire. "Violation of Fallow and Engineered Disaster in Mesopotamian Civilization," Irrigation's Impact on Society. Edited by Theodore E. Downing and McGuire Gibson. Tucson: University of Arizona Press, 1974.

19. Greene, Mark. "Impact of the Sahelian Drought in Mauritania," African Environment, I (1975), pp. 11-21.

20. Hare, F. Kenneth. Climate and Desertification. Toronto: University of Toronto, Institute for Environmental Studies, 1976. 
21. Hastenrath, S. "Variations in Low-latitude Circulation and Extreme Climatic Events in the Tropical Americas," Journal of Atmospheric Science, 33 (1976), pp. 202-15.

22. Hay, J. "Salt Cedar and Salinity on the Upper Rio Grande," The Careless Technology: Ecology and International Development. Edited by M. Taghi Farvar and John P. Milton. Garden City, New York: Natural History Press, 1972.

23. Johnson, Kirsten. "Do as the Land Requests": A Study of Otomi Resource-Use on the Eve of Irrigation. Ph.D. dissertation, Clark University, Graduate School of Geography, Worcester, Massachusetts, 1976.

24. Kassas, M. "A Brief History of Land-Use in Mareotis Region, Egypt," Minerva Biologica, 1 (1972), pp. 167-74.

25. Kates, R. W., D. L. Johnson, and K. Johnson. Population, Society and Desertification. Worcester, Mass.: Clark University, Program in International Development and Social Change, 1976.

26. Le Houérou, H. N. "Deterioration of the Ecological Equilibrium in the Arid Zones of North Africa," Special Publications of the Agronomical Research Organization, Volcani Centre, 39 (1974), pp. 54-57.

27. Lickiss, J. Norelle. "Health Problems of Urban Aborigines: With Special Reference to the Aboriginal People of Sydney," Social Science and Medicine, 9 (1975), pp. 313-18.

28. Malhotra, S. P., L. P. Bharara, and F. C. Patwa. "Introduction of Irrigation in Arid Rajasthan: A Case Study," Problems in the Development and Conservation of Desert and Semidesert Lands. Twenty-Third International Geographical Congress, Working Group on Desertification, Pre-Congress Symposium, Ashkhabad, USSR, 1976.

29. Markham, C. G. and D. R. McClain. "Sea Surface Temperature Related to Rain in Ceará, Northeastern Brazil," Nature, 265 (1977), pp. 320-23.

30. Marshall, J. K. "Principles of Soil Erosion and Its Prevention," The Use of Trees and Shrubs in the Dry Country of Australia. Canberra: Forestry and Timber Bureau, 1972.

31. Mason, B. J. "Towards the Understanding and Prediction of Climatic Variations," Quarterly Journal of the Royal Meteorological Society, 102 (1976), pp. 473-98.

32. Meckelein, W. "Desertification Caused by Land Reclamation in Deserts," Problems in the Development and Conservation of Desert and Semidesert Lands. 'Twenty-
Third International Geographical Congress, Working Group on Desertification, PreCongress Symposium, Ashkhabad, USSR, July 20-26, 1976 .

33. Mensching, H. and F. N. Ibrahim. "Problems of Desertification in the Northern Saharan Boundary Zone, the Steppe Region of the Maghrib and the Sahélian Zone," Cambridge Meeting on Desertification. International Geographical. Union, Working Group on Desertification, 1975.

34. Mott, G. O. "Grazing Pressure and Measurement of Pasture Production," Proceedings of the 8th International Grassland Congress, 8 (1960), pp. 606-11.

35. Newman, J. C. and R. W. Condon. "LandUse and Present Condition," Arid Lands in Australia. Edited by R. O. Slatyer and R. A. Perry. Canberra: Australian National University Press, 1969.

36. Nolan, Riall. "Labour Migration and the Bassari: A Case of Retrograde Development?" Man, 10 (1975), pp. 571-88.

37. Noy-Meir, I. "Desert Ecosystems: Environment and Producers," Annual Review of Ecology and Systematics, 4 (1973), pp. 25-51.

38. Noy-Meir, I. "Desert Ecosystems: Higher" Trophic Levels," Annual Review of Ecology and Systematics, 4 (1973), pp. 195-214.

39. O'Keefe, Philip. Gakarara: A Study in the Development of Underdevelopment. Occasional Paper No. 6, Disaster Research Unit, University of Bradford, 1975.

40. Ormerod, W. E. "Ecological Effect of Control of African Trypanosomiasis," Science, 191, No. 4229 (27 February, 1976), pp. 815-21.

41. Picardi, Anthony C. and William W. Seifert. "A Tragedy of the Commons in the Sahel," Technology Review, 78, No. 6 (1976), pp. 42-51.

42. Pittock, A. B. "Climatic Change and the Patterns of Variation in Australian Rainfall," Search, 6 (1975), pp. 498-504.

43. Rapp, A., H. N. Le Houérou, and B. Lundholm (eds.). Can Desert Encroachment Be Stopped? A Study with Emphasis on Africa. Ecological Bulletins No. 25. Stockholm: Swedish Natural Science Research Council, 1976.

44. Sandford, Stephen. The Design and Management of Pastoral Development: Human Pastoral Populations. Pastoral Network Paper 2c. London: Overseas Development Institute, Agricultural Administration Unit, 1977. 
45. Seamon, J., J. Rivers, J. Holt, and J. Murlis. "An Inquiry into the Drought Situation in Upper Volta," The Lancet, No. 7832 (October 6, 1973), pp. 774-78.

46. Sebai, Zohair A. The Health of the Bedouin Family in a Changing Arabia. Ph.D. dissertation. The Johns Hopkins University, School of Hygiene and Public Health, Baltimore, Md., 1969.

47. Singh, Gurdip. "The Indus Valley Culture Szen in the Context of Post-Glacial Climatic and Ecological Studies in North-West India," Archaeology and Physical Anthropology in Oceania, 6, No. 2 (July, 1971), pp. 177-89.

48. Singh, J., R. L. Singh, and K. N. Singh. "Rajasthan," India: A Regional Geography. Edited by R. L. Singh. Varanasi: National Geographical Society of India, 1971.

49. Talbot, Lce M. "Ecological Consequences of Rangeland Development in Masailand, East Africa," The Careless Technology: Ecology and International Development. Edited by M. Taghi Farvar and John P. Milton. Garden City, N.Y.: Natural History Press, 1972.
50. Tien, H. Yuan. China's Population Struggle: Demographic Decisions of the People's Republic, 1949-1969. Columbus, Ohio: The Ohio State University Press, 1973.

51. Tucker, G. B. "Climate: Is Australia's Changing?" Search, 6 (1975), pp. 323-28.

52. Tumbull, Colin M. The Mountain People. New York: Simon and Schuster, 1972.

53. Vita-Finzi, C. The Mediterranean Valleys: Geological Changes in Historical Time. Cambridge: Cambridge University Press, 1969.

54. Walker, J. and P. R. Rowntree. "The Effect of Soil Moisture on Circulation and Rainfall in a Tropical Model." MS. United Kingdom Meteorological Office, 1976.

55. Warren, A. and J. K. Maizels. Ecological Change and Desertification. London: University College, 1976.

56. Zghal, Abdelkader. Modernisation de l'agriculture et populations semi-nomades. Publications of the Institute of Social Studies, Series Major, Vol. 13. The Hague: Mouton, 1967. 